J. Dairy Sci. 95:4099-4108

http://dx.doi.org/10.3168/jds.2011-5127

(C) American Dairy Science Association ${ }^{\circledR}, 2012$.

\title{
Health recording in Canadian Holsteins: Data and genetic parameters
}

\author{
A. Koeck, ${ }^{\star 1}$ F. Miglior,†‡ D. F. Kelton, $\S$ and F. S. Schenkel ${ }^{\star}$ \\ ${ }^{*}$ Centre for Genetic Improvement of Livestock, University of Guelph, Guelph, Ontario, Canada, N1G 2W1 \\ †Guelph Food Research Centre, Agriculture and Agri-Food Canada, Guelph, Ontario, Canada, N1G 5C9 \\ ¥Canadian Dairy Network, Guelph, Ontario, Canada, N1K 1E5 \\ §Department of Population Medicine, Ontario Veterinary College, University of Guelph, Guelph, Ontario, Canada, N1G 2W1
}

\begin{abstract}
The objective of this study was to investigate if health data recorded by Canadian dairy producers can be used for genetic selection. Eight diseases are recorded by producers on a voluntary basis: mastitis, displaced abomasum, ketosis, milk fever, retained placenta, metritis, cystic ovaries, and lameness. Between 40 to $60 \%$ of all herds had to be excluded by editing procedures for each trait, assuming unreliable health recording. All analyses were carried out for first-lactation Holstein cows. The majority of disease cases occurred in the first month of lactation. Mean disease frequencies were 12.6, $3.7,4.5,4.6,10.8,8.2$, and $9.2 \%$ for mastitis, displaced abomasum, ketosis, retained placenta, metritis, cystic ovaries, and lameness, respectively. Milk fever was very rare in first-lactation cows with a frequency of only $0.20 \%$, and was, therefore, not considered in the analyses. Univariate and bivariate linear animal models were fitted. Heritabilities for mastitis, displaced abomasum, ketosis, retained placenta, metritis, cystic ovaries, and lameness were $0.02,0.06,0.03,0.03,0.02,0.03$, and 0.01 , respectively. Genetic correlations between diseases were mostly positive. The strongest genetic correlations were found between displaced abomasum and ketosis (0.64) and between retained placenta and metritis (0.62). The remaining genetic correlations ranged from -0.22 (between metritis and lameness) to 0.49 (between mastitis and lameness). In agreement with the genetic correlations, the largest phenotypic correlations were found between displaced abomasum and ketosis (0.27) and retained placenta and metritis (0.14). All other phenotypic correlations were low and close to zero (0.00 to 0.06). Pearson correlations between breeding values for health traits and other routinely evaluated traits were computed, which revealed noticeable favorable relationships to direct herd life and fertility. In addition, a moderate favorable association was found
\end{abstract}

Received November 7, 2011

Accepted February 18, 2012.

${ }^{1}$ Corresponding author: akoeck@uoguelph.ca between mastitis and somatic cell score. Mastitis is the most promising trait to be included in routine genetic evaluation, because it is the most recorded disease and has a high frequency and positive genetic correlations to all other health traits. Although, about $40 \%$ of all Canadian dairy producers participate in the healthrecording system, a large proportion of the data are lost after data validation. Thus, dairy producers should be encouraged to keep accurate and complete health data. Key words: heath trait, producer recorded data, data quality, genetic parameter

\section{INTRODUCTION}

Health traits are of increasing importance to dairy producers. In the Scandinavian countries, direct selection for improved disease resistance has been carried out for more than $30 \mathrm{yr}$ (Philipsson and Lindhé, 2003). In these countries, veterinary treatments are recorded, because all treatments involving antibiotics and hormones have to be made primarily by a veterinarian. As veterinarians have extensive knowledge in disease diagnoses, a large number of different health disorders are recorded (e.g., the Norwegian disease code includes 67 different diagnoses; Østerås et al., 2007). Recently, a similar disease-recording system has been established in Austria (Egger-Danner et al., 2010).

In Canada, a national dairy cattle health and disease data management system was started in 2007. The main objectives of this initiative are to provide information to dairy producers and their veterinarians for herd management and to establish a national genetic evaluation system for genetic selection for disease resistance. In contrast to the Scandinavian and Austrian approaches, the Canadian recording is done by producers. Eight diseases that are known to affect herd profitability are recorded by producers on a voluntary basis: mastitis, displaced abomasum, ketosis, milk fever, retained placenta, metritis, cystic ovaries, and lameness. Producers were provided with disease definitions, adapted from work by Kelton et al. (1998), as a guide for identification and recording of the diseases. Health data are recorded by producers using on-farm herd management software 
Table 1. Summary statistics of the health traits database

\begin{tabular}{|c|c|c|c|c|c|}
\hline Health category & Health event & $\begin{array}{l}\text { Number of } \\
\text { disease cases }\end{array}$ & $\begin{array}{l}\text { Percentage of } \\
\text { disease cases }\end{array}$ & $\begin{array}{l}\text { Number } \\
\text { of herds }\end{array}$ & $\begin{array}{c}\text { Percentage of } \\
\text { herds }\end{array}$ \\
\hline Mastitis & Mastitis & 154,292 & 40.3 & 4,927 & 86 \\
\hline Displaced abomasum & Displaced abomasum & 20,509 & 5.3 & 3,594 & 63 \\
\hline Milk fever & Milk fever & 15,157 & 3.9 & 2,704 & 47 \\
\hline Retained placenta & Retained placenta & 33,747 & 8.8 & 3,336 & 58 \\
\hline Metritis & Acute metritis & 22,686 & 5.9 & 2,043 & 36 \\
\hline Cystic ovaries & Cystic ovaries & 47,805 & 12.4 & 2,538 & 44 \\
\hline \multirow[t]{2}{*}{ Lameness } & Lameness & 46,542 & 12.1 & 2,923 & 51 \\
\hline & $\begin{array}{l}\text { Foot rot, laminitis, sole ulcer, } \\
\text { and other claw disorders }\end{array}$ & 2,077 & 0.5 & 410 & 7 \\
\hline Total & & 384,524 & 100 & 5,723 & \\
\hline
\end{tabular}

or record books. Data are collected by milk-recording technicians at each test-day herd visit and forwarded to the DHI association for the region [CanWest DHI (Guelph, ON, Canada) for Western Canada and Ontario; Valacta (Sainte-Anne-de-Bellevue, QC, Canada) for Atlantic Canada and Quebec]. Additionally, health data from producers participating in the Dossier Santé Animale/Animal Health Record program is collected and forwarded to the DHI database by their veterinarians. All data are stored in the national database at the Canadian Dairy Network (Guelph, ON, Canada). In 2010 , about $30 \%$ of all recorded disease cases originated from on-farm herd management software, $30 \%$ from record books, and 40\% from the Dossier Santé Animale/ Animal Health Record program.

The feasibility of using producer-recorded health data for genetic evaluations has been shown previously based on data from the United States (Zwald et al., 2004a,b), Australia (Haile-Mariam and Goddard, 2010), and UK (Kadarmideen et al., 2000; Pritchard et al., 2010). However, routine genetic evaluations for health traits based on producer-recorded data have not been implemented so far in any of these countries. One of the reasons is that it is difficult to get accurate health data from a large number of herds.

In Canada, Neuenschwander et al. (2012) estimated genetic parameters for producer-recorded health data in Holstein cows, but the data was limited and included only $1 \mathrm{yr}$ of records. In this study, Canadian health data from a longer period (4 yr) was analyzed. The overall objective was to investigate if these data can be used for genetic evaluation. The specific objectives were 1) to assess data quality, 2) to calculate disease frequencies, 3) to estimate heritabilities and genetic and phenotypic correlations for health traits, and 4) to obtain breeding values for health traits and examine relationships with other routinely evaluated traits.

\section{MATERIALS AND METHODS}

\section{Data}

Database. Health data from April 1, 2007 to April 20, 2011 were obtained from the Canadian Dairy Network. A summary of current data in the database is given in Table 1. The database consisted of 384,524 disease cases from 187,592 cows, of which $95.4 \%$ were from Holstein, 2.4\% from Ayrshire, and 1.7\% from Jersey cows. A total of 5,723 herds were represented. Recording of mastitis was done in the majority of herds (89\%), displaced abomasum in $63 \%$ of herds, and retained placenta in $58 \%$ of herds. Only $16 \%$ of herds had records for all 8 health categories.

The number of reported disease cases per year has shown a continuous increase (Table 2). In contrast, the total number of herds recording health data remained almost unchanged in the last $3 \mathrm{yr}$. Thus, the increase in reported disease cases per year is mainly due to a greater effort in health recording of the participating herds. As shown in Table 2, the average number of reported disease cases per herd increased from 2007 to 2010.

Data Validation and Editing. To ensure that all cows were from herds with reliable health recording, several editing criteria were applied separately for each disease. Only herds having at least 2 records of a specific disease were considered. The first and last record had to be at least $180 \mathrm{~d}$ distant to remove herds that had done recording just for a short time period. In addition, minimum disease frequencies were applied to ensure continuous data recording within individual herds. Minimum frequencies (reported cases per herd and year) were $5 \%$ for mastitis and $1 \%$ for the other diseases. Between 40 to $60 \%$ of all herds had to be excluded by editing procedures for each trait. 
Table 2. Development of health data recording from 2007 to 2011

\begin{tabular}{lcccc}
\hline Year & $\begin{array}{c}\text { Number of } \\
\text { disease cases }\end{array}$ & $\begin{array}{c}\text { Number } \\
\text { of herds }\end{array}$ & $\begin{array}{c}\text { Mean number of } \\
\text { cows per herd }\end{array}$ & $\begin{array}{c}\text { Mean number of } \\
\text { disease cases per herd }\end{array}$ \\
\hline 2007 & 49,471 & 3,086 & 67 & 16 \\
2008 & 94,723 & 3,923 & 66 & 24 \\
2009 & 110,511 & 3,983 & 68 & 29 \\
2010 & 117,932 & 4,071 & - & - \\
$2011^{1}$ & 11,877 & - & - & \\
\hline
\end{tabular}

${ }^{1}$ Until April 20, 2011.

Holstein is the most common dairy cattle breed in Canada (constituting up to $90 \%$ of the dairy cows) and, therefore, almost all health records were from Holstein cows. For this reason, analyses were carried out for this breed only. Only records from first-lactation cows with an age between 19 and 43 mo were considered.

Trait Definition. Health disorders were defined as binary traits $(0=$ no case, $1=$ at least one case $)$ based on whether or not the cow had at least 1 disease case recorded within the first $14 \mathrm{~d}$ after calving for retained placenta, within $100 \mathrm{~d}$ after calving for ketosis, within $150 \mathrm{~d}$ after calving for metritis (i.e., for acute metritis, purulent discharge, endometritis, and chronic metritis, because the diagnosis metritis includes all cases) and within $305 \mathrm{~d}$ after calving for mastitis, displaced abomasum, cystic ovaries, and lameness (includes also cases for foot rot, laminitis, sole ulcer, and other claw disorders, only recorded in a limited number of herds). Milk fever had a very low incidence in first-lactation cows $(0.20 \%)$, and was, therefore, not considered in the analyses. Summary statistics of the analyzed data are given in Table 2.

Pedigree. The animal pedigree file was generated by tracing the pedigrees of cows with data 7 generations back and contained the relationship of 566,088 animals.

\section{Model}

Univariate and bivariate linear animal models were fitted using the average information-restricted maximum likelihood (AI-REML) procedure in the derivativefree approach to multivariate analysis (DMU) package (Madsen and Jensen, 2008). Although threshold models are, at least in theory, more appropriate to analyze binary traits, linear models were applied. In a previous study on Canadian health data, Neuenschwander (2010) found that the use of threshold models did not improve the goodness of fit compared with linear models. Other studies have shown the same (e.g., Negussie et al., 2008). Besides, genetic correlations are reported to be correct for binary traits using linear models (e.g., Heringstad et al., 2005a; Negussie et al., 2008).
Univariate Linear Model. Univariate analyses were run for mastitis, displaced abomasum, ketosis, retained placenta, metritis, cystic ovaries, and lameness. The following linear animal model was applied:

$$
\mathbf{y}=\mathbf{X} \boldsymbol{\beta}+\mathbf{Z}_{\mathbf{h}} \mathbf{h}+\mathbf{Z}_{\mathrm{a}} \mathbf{a}+\mathbf{e},
$$

where $\mathbf{y}$ is a vector of observations for the disease trait; $\boldsymbol{\beta}$ is a vector of systematic effects, including fixed effects of age at calving and year-season of calving; $\mathbf{h}$ is a vector of random herd-year of calving effects; a is a vector of random animal effects; $\mathbf{e}$ is a vector of random residuals; and $\mathbf{X}, \mathbf{Z}_{\mathrm{h}}$, and $\mathbf{Z}_{\mathrm{a}}$ are the corresponding incidence matrices. Age at first calving had 16 classes, in which $<22$ and $>35$ mo were the first and last class, respectively, and other classes were single months. Four seasons of calving were defined: January to March, April to June, July to September, and October to December.

Random effects were assumed to be normally distributed with means equal to zero and covariance structure equal to

$$
\operatorname{Var}\left[\begin{array}{l}
\mathbf{h} \\
\mathbf{a} \\
\mathbf{e}
\end{array}\right]=\left[\begin{array}{ccc}
\mathbf{I} \sigma_{\mathrm{h}}^{2} & 0 & 0 \\
& \mathbf{A} \sigma_{\mathrm{a}}^{2} & 0 \\
\mathbf{s y m m} . & \mathbf{I} \sigma_{\mathrm{e}}^{2}
\end{array}\right],
$$

where $\sigma_{\mathrm{h}}^{2}, \sigma_{\mathrm{a}}^{2}$, and $\sigma_{\mathrm{e}}^{2}$ are the herd-year, animal, and residual variances, respectively; $\mathbf{I}$ is an identity matrix; and $\mathbf{A}$ is the additive genetic relationship matrix.

Bivariate Linear Model. Bivariate analyses were performed among 1) acute metritis, purulent discharge, endometritis, and chronic metritis, and 2) mastitis, displaced abomasum, ketosis, retained placenta, metritis, cystic ovaries, and lameness. Fixed and random effects were as in the univariate model.

Random effects were assumed to be normally distributed with means equals to zero and covariance structure equal to: 


$$
\operatorname{Var}\left[\begin{array}{l}
\mathbf{h} \\
\mathbf{a} \\
\mathbf{e}
\end{array}\right]=\left[\begin{array}{ccc}
\mathbf{H}_{0} \otimes \mathbf{I} & 0 & 0 \\
& \mathbf{G}_{0} \otimes \mathbf{A} & 0 \\
\mathbf{s y m m} . & & \mathbf{R}_{0} \otimes \mathbf{I}
\end{array}\right],
$$

where

$$
\mathbf{H}_{0}=\left[\begin{array}{ll}
\sigma_{\mathbf{h} 1}^{2} & \sigma_{\mathbf{h} 1 \mathbf{h} 2} \\
\sigma_{\mathbf{h} 1 \mathbf{h} 2} & \sigma_{\mathbf{h} 2}^{2}
\end{array}\right]
$$

is the (co)variance matrix between traits due to herdyear of calving effects,

$$
\mathbf{G}_{0}=\left[\begin{array}{ll}
\sigma_{\mathrm{a} 1}^{2} & \sigma_{\mathrm{a} 1 \mathbf{a} 2} \\
\sigma_{\mathrm{a} 1 \mathbf{a} 2} & \sigma_{\mathbf{a} 2}^{2}
\end{array}\right]
$$

is the (co)variance matrix between traits due to animal additive genetic effects, and

$$
\mathbf{R}_{0}=\left[\begin{array}{ll}
\sigma_{\mathbf{e} 1}^{2} & \sigma_{\mathbf{e} 1 \mathbf{e} 2} \\
\sigma_{\mathbf{e} 1 \mathbf{e} 2} & \sigma_{\mathbf{e} 2}^{2}
\end{array}\right]
$$

is the (co)variance matrix between traits due to residual effects.

Heritability estimates $\left[\mathrm{h}^{2}=\sigma_{\mathbf{a}}^{2} /\left(\sigma_{\mathbf{a}}^{2}+\sigma_{\mathbf{h}}^{2}+\sigma_{\mathbf{e}}^{2}\right)\right]$ were calculated as the average estimate from all bivariate analyses for each trait. The corresponding standard errors were calculated in the same way.

\section{Breeding Value Estimation}

Breeding values of sires with at least 30 daughters for all health traits were obtained from univariate analyses as described above. Estimated breeding values were reversed in sign. Thus, higher EBV indicate sires with daughters more resistant to diseases. Pearson correlations of sire EBV for health traits with official EBV of other routinely evaluated traits were computed. Minimum standards that are established for the official publication of bull proofs can be looked up at Canadian Dairy Network (2010).

\section{RESULTS AND DISCUSSION}

\section{Participation and Data Quality}

According to the Canadian Dairy Information Centre (2012), a total of 9,721 herds with an average herd size of 72 cows were under milk recording in 2010. In the same year, 4,071 herds recorded health data (Table 2), which accounts for $42 \%$ of all herds under milk recording. A similar participation has been achieved in the newly established health monitoring system in Austria. By February 2010, 54\% of all dairy herds participated in the Austrian health monitoring system; however, only $66 \%$ of these herds recorded health data (EggerDanner et al., 2010). This means that in $36 \%$ of all Austrian dairy herds health data are actually recorded.

In the present study, between 40 to $60 \%$ of all herds had to be excluded by the editing procedures applied. This was expected, because the recording system is relatively new. Similar values were reported in previous studies. Pryce et al. (1997) discarded $42 \%$ of all herds during editing procedures based on health data from the UK. Using producer-recorded health data from the United States, Zwald et al. (2004a) excluded 17\% (for displaced abomasum) to $64 \%$ (for lameness) of all herds, assuming unreliable documentation and recording. Based on Australian data, Haile-Mariam and Goddard (2010) excluded 50\% (for all disorders) to $85 \%$ (for leg disorders) of all herds.

The results of the present study revealed that future work is necessary to increase participation and data quality in the Canadian health-recording system. It is especially important to highlight the benefits of disease recording for herd management and genetic evaluations to dairy producers.

\section{Disease Occurrence}

Figure 1 shows the distribution of first occurrence of each disorder according to days after calving in firstlactation Holstein cows. A high proportion (35\%) of mastitis cases occurred in the first month of lactation, whereas the remaining cases were equally distributed across lactation. Almost all cases of ketosis (99\%) and displaced abomasum (91\%) occurred during the first $100 \mathrm{~d}$ of lactation. Cases of retained placenta and metritis were concentrated around calving, whereas cases of cystic ovaries were reported mainly during the breeding period. Cases of lameness were more evenly distributed throughout the lactation, with slightly more cases in early lactation. The increased occurrence of diseases in the first month of lactation was also observed in previous studies (e.g., Zwald et al., 2004a). In this period, cows are facing high physiological demands, which include onset of lactation, alternations in immune mechanism, and increased lipid metabolism (Sordillo et al., 2009).

\section{Disease Frequencies}

After editing, mean disease frequencies were 12.6, $3.7,4.5,4.6,10.8,8.2$, and $9.2 \%$ for mastitis, displaced 
Mastitis ( $\mathrm{n}=7,812)$

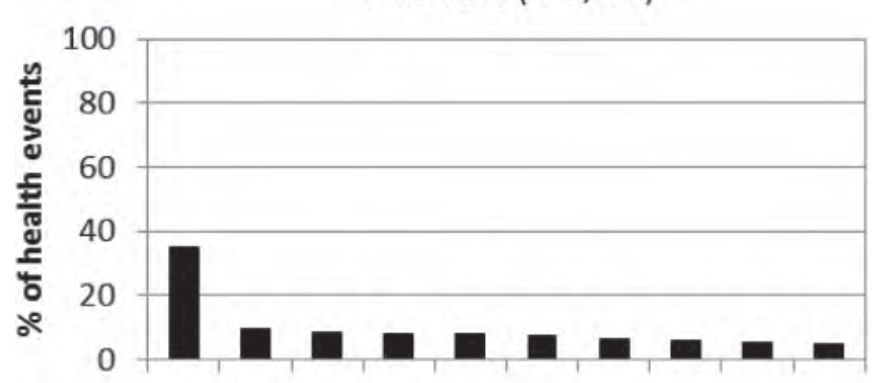

Ketosis $(n=827)$

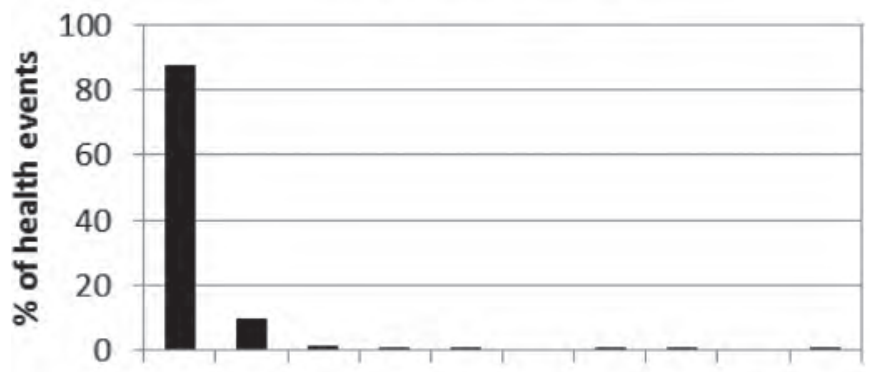

- Metritis ( $n=5,390)$

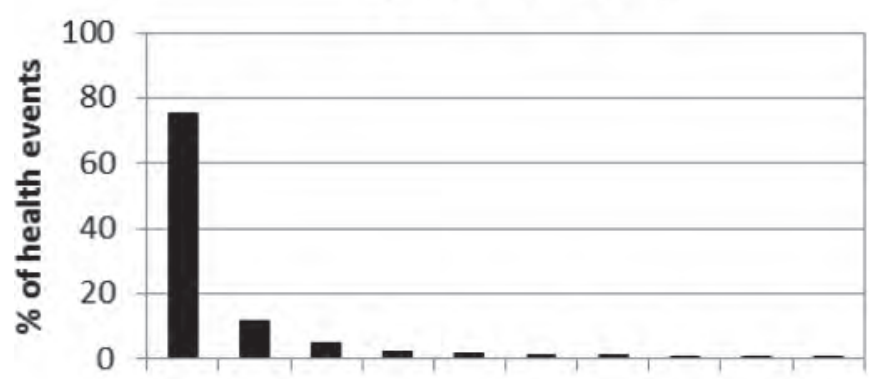

- Lameness $(\mathrm{n}=3,327)$

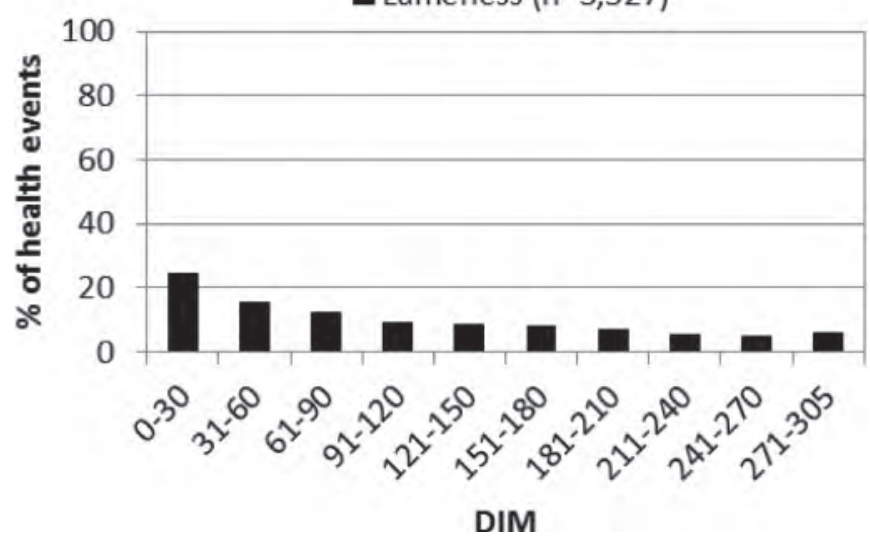

- Displaced abomasum $(n=1,637)$

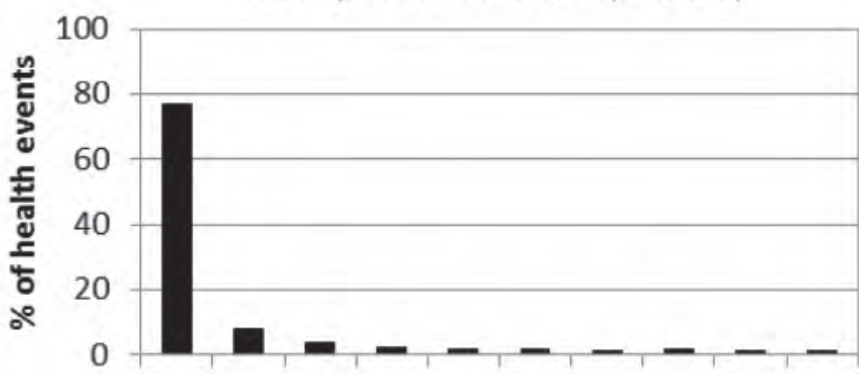

- Retained placenta $(n=2,728)$

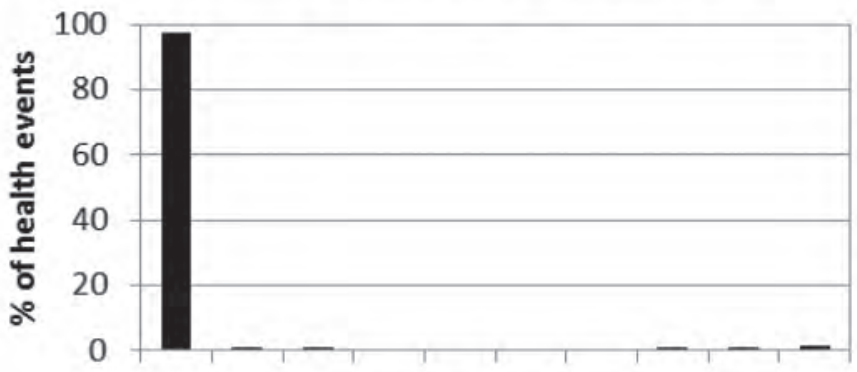

-Cystic ovaries $(n=3,807)$

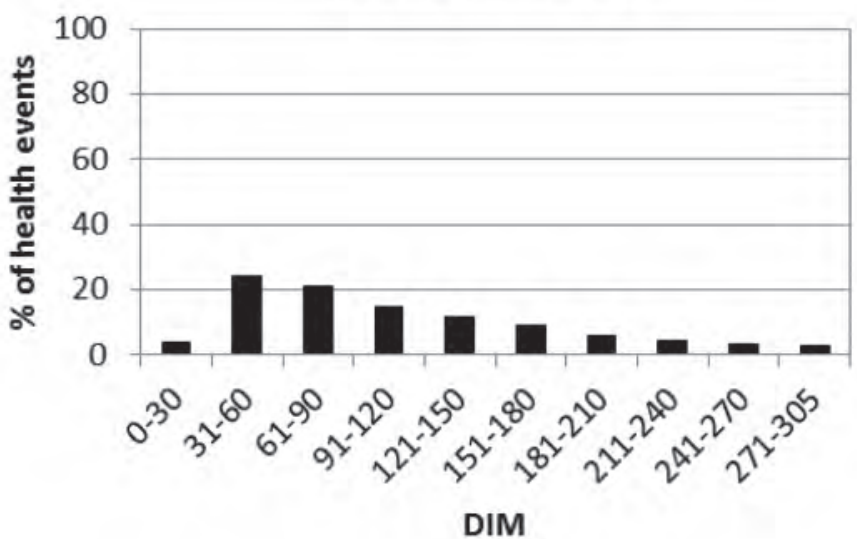

Figure 1. Occurrence of first incidence of each health disorder by stage of lactation in first-lactation Holstein cows [\% of disease cases in each interval $(\mathrm{n}=$ number of disease cases $)]$. 
KOECK ET AL.

Table 3. Summary statistics of analyzed data in first-lactation Holstein cows

\begin{tabular}{lccrc}
\hline Trait & $\begin{array}{c}\text { Days from } \\
\text { calving }\end{array}$ & $\begin{array}{c}\text { No. of } \\
\text { records }\end{array}$ & $\begin{array}{c}\text { No. of } \\
\text { herds }\end{array}$ & $\begin{array}{c}\text { Frequency } \\
\text { (\%) }\end{array}$ \\
\hline Mastitis & 0 to 305 & 61,800 & 1,864 & 12.6 \\
Displaced abomasum & 0 to 305 & 43,833 & 1,293 & 3.7 \\
Ketosis & 0 to 100 & 26,802 & 776 & 4.5 \\
Retained placenta & 0 to 14 & 86,005 & 1,684 & 4.6 \\
Metritis $^{1}$ & 0 to 150 & 59,575 & 1,464 & 10.8 \\
Acute metritis & 0 to 150 & 33,522 & 763 & 10.3 \\
Purulent discharge & 0 to 150 & 19,392 & 636 & 8.3 \\
Endometritis & 0 to 150 & 6,733 & 222 & 6.5 \\
Chronic metritis $_{\text {Cystic ovaries }}$ & 0 to 150 & 16,701 & 593 & 5.8 \\
Lameness $^{2}$ & 0 to 305 & 46,341 & 1,248 & 8.2 \\
\hline
\end{tabular}

${ }^{1}$ Metritis included cases for acute metritis, purulent discharge, endometritis, and chronic metritis.

${ }^{2}$ Lameness included cases for lameness, foot rot, laminitis, sole ulcer, and other claw disorders.

abomasum, ketosis, retained placenta, metritis, cystic ovaries, and lameness, respectively (Table 3 ). In a literature review, Kelton et al. (1998) found similar disease frequencies across studies: $14.2 \%$ for mastitis, $1.7 \%$ for displaced abomasum, $4.8 \%$ for ketosis, $8.6 \%$ for retained placenta, $10.1 \%$ for metritis, $8.0 \%$ for cystic ovaries, and $7.0 \%$ for lameness. In a more recent study in US Holstein cows, Zwald et al. (2004a) reported higher frequencies for mastitis (20\%), ketosis (10\%), and metritis (including retained placenta, 21\%), whereas frequencies for displaced abomasum (3\%), cystic ovaries (8\%), and lameness $(10 \%)$ were in agreement with our study. In UK Holstein cows, Kadarmideen et al. (2000) found a mastitis frequency of $6 \%$ across lactations. In a more recent study by Pritchard et al. (2010), the mastitis frequency in first-lactation UK Holstein cows was $12.3 \%$, which reflects the greater effort in farmer recording since the previous study by Kadarmideen et al. (2000).

\section{Heritabilities and Genetic and Phenotypic Correlations}

Heritabilities and genetic and phenotypic correlations for acute metritis, purulent discharge, endometritis, and chronic metritis are given in Table 4. Heritability estimates were $0.01,0.03,0.02$, and 0.01 for acute metritis, purulent discharge, endometritis, and chronic metritis, respectively. Genetic correlations among these traits were not different from 1 , as standard errors were large. The results imply that a single code would be sufficient for the different metritis traits. Phenotypic correlations ranged from 0.09 (between endometritis and chronic metritis) to 0.28 (between purulent discharge and endometritis). In the subsequent analyses acute metritis, purulent discharge, endometritis, and chronic metritis were considered together as 1 trait (metritis).

Heritabilities for mastitis, displaced abomasum, ketosis, retained placenta, metritis, cystic ovaries, and lameness were $0.02,0.06,0.03,0.03,0.02,0.03$, and 0.01 , respectively (Table 5 ). These estimates are in the range of previous studies using linear models. Heringstad et al. (2000) conducted a literature review and found heritability estimates in the range from 0.001 to 0.06 for mastitis, with most values in the interval from 0.02 to 0.03 . In UK Holstein cows, Kadarmideen et al. (2000) obtained heritabilities of 0.04, 0.02, and 0.01 for mastitis, lameness and ketosis, respectively. Dechow et al. (2004) reported heritability estimates in the range of 0.005 for reproductive disorders to 0.08 for displaced abomasum.

Genetic correlations among health traits are given in Table 5. The strongest genetic correlations were found between displaced abomasum and ketosis (0.64) and between retained placenta and metritis (0.62). Moderate

Table 4. Heritabilities (in bold on the diagonal, with SE in parentheses), genetic correlations (above the diagonal, with SE in parentheses), and phenotypic correlations (below the diagonal; SE not available) for acute metritis, purulent discharge, endometritis, and chronic metritis from bivariate linear animal model analyses

\begin{tabular}{lllll}
\hline Trait & \multicolumn{1}{c}{$\begin{array}{c}\text { Acute } \\
\text { metritis }\end{array}$} & $\begin{array}{c}\text { Purulent } \\
\text { discharge }\end{array}$ & Endometritis & $\begin{array}{c}\text { Chronic } \\
\text { metritis }\end{array}$ \\
\hline Acute metritis & $\mathbf{0 . 0 1}(0.004)$ & $0.99(0.12)$ & $0.76(0.35)$ & $1.00(0.26)$ \\
Purulent discharge & 0.13 & $\mathbf{0 . 0 3}(0.008)$ & $0.99(0.18)$ & $0.94(0.26)$ \\
Endometritis & 0.17 & 0.28 & $\mathbf{0 . 0 2}(0.013)$ & $0.99(0.36)$ \\
Chronic metritis & 0.10 & 0.21 & 0.09 & $\mathbf{0 . 0 1}(0.005)$ \\
\hline
\end{tabular}


Table 5. Heritabilities (in bold on the diagonal, with SE in parentheses), genetic correlations (above the diagonal, with SE in parentheses), and phenotypic correlations (below the diagonal; SE not available) for mastitis, displaced abomasum, ketosis, retained placenta, metritis, cystic ovaries, and lameness from bivariate linear animal model analyses

\begin{tabular}{|c|c|c|c|c|c|c|c|}
\hline Trait & Mastitis & $\begin{array}{c}\text { Displaced } \\
\text { abomasum }\end{array}$ & Ketosis & $\begin{array}{l}\text { Retained } \\
\text { placenta }\end{array}$ & Metritis & $\begin{array}{l}\text { Cystic } \\
\text { ovaries }\end{array}$ & Lameness \\
\hline Mastitis & $\mathbf{0 . 0 2}(0.004)$ & $0.20(0.12)$ & $0.36(0.15)$ & $0.29(0.13)$ & $0.20(0.15)$ & $0.19(0.15)$ & $0.49(0.16)$ \\
\hline Displaced abomasum & 0.01 & $\mathbf{0 . 0 6}(0.008)$ & $0.64(0.10)$ & $-0.07(0.12)$ & $0.44(0.12)$ & $-0.11(0.13)$ & $0.31(0.16)$ \\
\hline Retained placenta & 0.02 & 0.02 & 0.03 & $\mathbf{0 . 0 3}(0.005)$ & $0.62(0.11)$ & $0.23(0.14)$ & $0.11(0.19)$ \\
\hline Metritis $^{1}$ & 0.02 & 0.06 & 0.05 & 0.14 & $\mathbf{0 . 0 2}(0.004)$ & $0.04(0.16)$ & $-0.22(0.19)$ \\
\hline Cystic ovaries & 0.01 & 0.02 & 0.00 & 0.01 & 0.03 & $\mathbf{0 . 0 3}(0.005)$ & $0.08(0.20)$ \\
\hline
\end{tabular}

${ }^{1}$ Metritis included cases for acute metritis, purulent discharge, endometritis, and chronic metritis.

${ }^{2}$ Lameness included cases for lameness, foot rot, laminitis, sole ulcer, and other claw disorders.

positive estimates were also found between mastitis and ketosis (0.36), mastitis and retained placenta (0.29), mastitis and lameness (0.49), displaced abomasum and metritis (0.44), displaced abomasum and lameness (0.31), and ketosis and metritis (0.32).

Zwald et al. (2004b) obtained genetic correlations in the range of -0.01 (between mastitis and metritis) to 0.45 (between displaced abomasum and ketosis) among various health disorders. Low to moderate genetic correlations from -0.10 to 0.40 among mastitis, ketosis, milk fever, and retained placenta were reported by Heringstad et al. (2005b). Analyzing fertility disorders in first-lactation Norwegian Red cows, Heringstad (2010) found also a high positive genetic correlation of 0.64 between metritis and retained placenta. However, in contrast to our results, a significant negative genetic correlation of -0.26 was estimated between retained placenta and cystic ovaries.

In the present study, genetic correlations between diseases were mostly positive. This is also consistent with the results from a selection experiment with Norwegian Red cows, where it was shown that selection against mastitis leads to favorable correlated selection responses in other diseases, such as ketosis and retained placenta (Heringstad et al., 2007), thus indicating the existence of a general immune response. In a recent study by De La Paz (2008), it was found that cows with both high antibody and cell-mediated immune response have a decreased risk of disease occurrence for several diseases, including mastitis, ketosis, metritis, and retained placenta, compared with cows identified as low responders. As shown by Thompson-Crispi et al. (2012), immune response traits are moderately heritable in Holsteins. A heritability of $0.19(\mathrm{SE}=0.10)$ was found for cell-mediated immune response, whereas for antibody-mediated immune response traits heritabilities ranged from 0.16 to 0.41 ( $\mathrm{SE}=0.09-0.11$ ).

Phenotypic correlations among health traits are given in Table 5. The largest phenotypic correlations were found between displaced abomasum and ketosis $(0.27)$ and retained placenta and metritis (0.14). All other phenotypic correlations were low, ranging from 0.00 to 0.06 .

\section{$E B V$}

Estimated breeding values from univariate analyses of sires with at least 30 daughters were sampled and are given in Table 6, showing the percentage of diseased daughters of all, the best (10\% quantile), and worst (90\% quantile) sires according to their EBV for resistance to mastitis, displaced abomasum, ketosis, retained placenta, metritis, cystic ovaries, and lameness. Despite the low heritability of health traits, large differences between daughter groups were observed. For mastitis, the percentage of diseased daughters varied between 7 and $20 \%$ among the sires with the best and worst EBV. In other words, for the worst bulls, 1 out of 5 daughters had a mastitis case in her first lactation, whereas only 1 out of 14 daughters of the best sires was affected by mastitis. A similar pattern was observed for the other diseases, which indicates sufficient genetic variation to exploit by breeding for health traits.

\section{Associations with Other Routinely Evaluated Traits}

Correlations of sire EBV for health traits with other routinely evaluated traits are shown in Table 7. Routinely evaluated traits in Canada, with the exception of SCS, are scored to have a higher EBV being favorable. As expected from literature results (e.g., Heringstad et al., 2000), cows with a higher genetic merit for milk yield were more susceptible to mastitis, cystic ovaries, and lameness. Direct herd life was positively associated with all health traits, suggesting that selection for disease resistance would improve longevity as well, which is in agreement with previous studies (e.g., Holtsmark 
Table 6. Percentage of diseased daughters of all, the best (10\% quantile), and worst (90\% quantile) sires according to their EBV for resistance to mastitis, displaced abomasum, ketosis, retained placenta, metritis, cystic ovaries, and lameness from univariate linear animal model analyses

\begin{tabular}{lcrcc}
\hline & & \multicolumn{3}{c}{ Percentage of diseased daughters } \\
\cline { 3 - 5 } Trait & $\begin{array}{c}\text { No. of } \\
\text { sires }\end{array}$ & Mean & 10\% quantile & $90 \%$ quantile \\
\hline Mastitis & 220 & 13.4 & 7.3 & 20.1 \\
Displaced abomasum & 151 & 3.4 & 0.4 & 8.7 \\
Ketosis & 110 & 4.6 & 2.3 & 10.0 \\
Retained placenta & 299 & 4.9 & 1.5 & 10.3 \\
Metritis $^{2}$ & 193 & 11.3 & 7.7 & 16.0 \\
Cystic ovaries $^{3}$ & 154 & 8.8 & 4.6 & 15.0 \\
Lameness $^{3}$ & 127 & 9.2 & 4.9 &
\end{tabular}

${ }^{1}$ Only sires with at least 30 daughters were considered.

${ }^{2}$ Metritis included cases for acute metritis, purulent discharge, endometritis, and chronic metritis.

${ }^{3}$ Lameness included cases for lameness, foot rot, laminitis, sole ulcer, and other claw disorders.

et al., 2008; Onyiro et al., 2008). A moderate, favorable association was found between SCS and mastitis.

In a recent study in Canadian Holsteins, a genetic correlation of 0.69 was estimated between mastitis and average SCS in early lactation (Koeck et al., 2012). In a literature review, Heringstad et al. (2000) reported that estimates of genetic correlations between mastitis and SCC ranged from 0.3 to 0.8 , with an average of 0.6 , based on Nordic field data. These results imply that although mastitis and SCS have some common genetic background they are not the same trait.

Maternal calving ease was desirably associated with retained placenta and metritis, which indicates that cows with an easier calving have fewer reproductive problems. Phenotypically, dystocia increases the incidence of retained placenta and uterine disease (Mee,
2008). However, genetic studies investigating these traits are limited. A low positive, albeit nonsignificant, genetic correlation between retained placenta and calving difficulty was found by Schnitzenlehner et al. (1998).

In previous studies, low to moderate, favorable genetic correlations were reported between health and fertility traits (e.g., Holtsmark et al., 2008; Onyiro et al., 2008). Also, in the present study, favorable associations were found between these traits, indicating that cows that are more resistant to diseases have higher fertility.

Mammary system, as an overall udder trait, showed a favorable association with mastitis. Previously, higher udders and strongly attached fore udders have been associated with lower mastitis incidence (e.g., Sørensen

Table 7. Pearson correlations between EBV of sires with at least 30 daughters for resistance to mastitis, displaced abomasum, ketosis, retained placenta, metritis, cystic ovaries, and lameness and other routinely evaluated traits

\begin{tabular}{|c|c|c|c|c|c|c|c|}
\hline Trait & $\begin{array}{c}\text { Mastitis } \\
(220 \text { sires })\end{array}$ & $\begin{array}{l}\text { Displaced } \\
\text { abomasum } \\
\text { (151 sires) }\end{array}$ & $\begin{array}{c}\text { Ketosis } \\
\text { (110 sires) }\end{array}$ & $\begin{array}{c}\text { Retained } \\
\text { placenta } \\
(299 \text { sires })\end{array}$ & $\begin{array}{l}\text { Metritis }{ }^{1} \\
\text { (193 sires) }\end{array}$ & $\begin{array}{c}\text { Cystic } \\
\text { ovaries } \\
\text { (154 sires) }\end{array}$ & $\begin{array}{l}\text { Lameness }^{2} \\
\text { (127 sires) }\end{array}$ \\
\hline Milk yield (1st lactation) & $-0.31^{* * *}$ & -0.02 & 0.01 & -0.10 & 0.09 & $-0.22^{* *}$ & $-0.32^{* * *}$ \\
\hline Protein yield (1st lactation) & $-0.26^{* * *}$ & 0.02 & 0.01 & $-0.15^{*}$ & 0.11 & $-0.24^{* *}$ & $-0.31^{* * *}$ \\
\hline Fat yield (1st lactation) & -0.06 & -0.05 & -0.15 & -0.07 & -0.03 & 0.02 & $-0.20^{*}$ \\
\hline Direct herd life (1st lactation) & $0.24^{* * *}$ & $0.44^{* * *}$ & $0.31^{* *}$ & $0.18^{* *}$ & $0.18^{*}$ & $0.22^{* *}$ & $0.36^{* * *}$ \\
\hline Somatic cell score (1st lactation) & $-0.40^{* * *}$ & -0.07 & -0.11 & -0.12 & -0.14 & -0.11 & -0.13 \\
\hline Calving ease maternal (heifers) & 0.00 & 0.03 & -0.08 & $0.19^{* *}$ & $0.34 * * *$ & -0.02 & -0.04 \\
\hline Calving to first service & $0.30^{* * *}$ & $0.20^{*}$ & 0.18 & 0.09 & 0.12 & 0.02 & 0.09 \\
\hline 56-d nonreturn rate (cows) & -0.03 & 0.14 & 0.02 & $0.21 * * *$ & $0.16^{*}$ & $0.28^{* * *}$ & 0.02 \\
\hline Number of services (cows) & 0.12 & $0.20^{*}$ & 0.10 & $0.28 * * *$ & $0.25^{* * *}$ & $0.30 * * *$ & 0.15 \\
\hline First service to conception (cows) & $0.17^{*}$ & $0.20^{*}$ & 0.08 & $0.26 * * *$ & $0.26 * * *$ & $0.28 * * *$ & 0.15 \\
\hline Days open & $0.25 * * *$ & $0.22^{* *}$ & 0.14 & $0.24^{* * *}$ & $0.25^{* * *}$ & $0.22^{* *}$ & 0.15 \\
\hline Overall conformation & $0.22^{* *}$ & -0.06 & 0.15 & $0.19^{* *}$ & 0.02 & 0.04 & 0.12 \\
\hline Overall mammary system & $0.18^{* *}$ & 0.05 & $0.23^{*}$ & $0.14^{*}$ & 0.02 & -0.01 & 0.01 \\
\hline Overall feet and legs & 0.09 & 0.02 & 0.11 & 0.06 & 0.04 & 0.06 & $0.18^{*}$ \\
\hline
\end{tabular}

${ }^{1}$ Metritis included cases for acute metritis, purulent discharge, endometritis, and chronic metritis.

${ }^{2}$ Lameness included cases for lameness, foot rot, laminitis, sole ulcer, and other claw disorders.

${ }^{*} P<0.05 ;{ }^{* *} P<0.01 ;{ }^{* * *} P<0.001$. 
et al., 2000). However, the biological reason for the favorable associations of mammary system with ketosis and retained placenta is unclear. The overall score for feet and legs was positively associated with lameness, confirming the results of Onyiro et al. (2008) and van der Linde et al. (2010).

\section{CONCLUSIONS}

The present study showed the potential to use producer-recorded health data for genetic evaluations in Canada. Disease frequencies, genetic parameters, and EBV correlations with other routinely evaluated traits were in line with previous studies. Mastitis is the most-recorded disease and, with its high frequency and positive genetic correlations to all other health traits, it is the most promising trait to be included in routine genetic evaluation. About $40 \%$ of all Canadian dairy producers participate in the health-recording system; however, a large proportion of the data are lost after data validation. Thus, dairy producers should be encouraged to keep accurate and complete health data.

\section{ACKNOWLEDGMENTS}

All dairy producers recording health data are gratefully acknowledged. This study was funded by the DairyGen council of Canadian Dairy Network (Guelph, Ontario, Canada) and the Natural Sciences and Engineering Research Council of Canada (Ottawa, Ontario, Canada). The authors thank 3 anonymous reviewers for their valuable comments and suggestions.

\section{REFERENCES}

Canadian Dairy Information Centre. 2012. Enrollments on milk recording. Accessed Jan. 31, 2012. http://www.dairyinfo.gc.ca/index_e. php?s1=dff-fcil\&s2=mrr-pcle\&s3=dhi-agbl\&page $=$ emr-ipcl.

Canadian Dairy Network. 2010. Criteria for an official bull proofJanuary 2010. Accessed Jan. 31, 2012. http://www.cdn.ca/articles. php.

Dechow, C. D., G. W. Rogers, U. Sander-Nielsen, L. Kiel, T. J. Lawlor, J. S. Clay, A. E. Freeman, G. Abdel-Azim, A. Kuck, and S. Schnell. 2004. Correlations among body conditions scores from various sources, dairy form, and cow health from the United States and Denmark. J. Dairy Sci. 87:3526-3533.

De La Paz, J. M. 2008. Using humoral and cellular response to novel antigens in periparturient dairy cows as a measure of genetic disease resistance in dairy cows. MSc Thesis. University of Florida, Gainesville.

Egger-Danner, C., W. Obritzhauser, B. Fuerst-Waltl, B. Grassauer, R. Janacek, F. Schallerl, C. Litzllachner, A. Koeck, M. Mayerhofer, M. Miesenberger, G. Schoder, F. Sturmlechner, A. Wagner, and K. Zottl. 2010. Registration of direct health traits in Austria-Experience review. Pages 69-77 in Proc. ICAR 37th Annual Meeting, Riga, Latvia. E. Skujina, E. Galvanoska, O. Leray, and C. Mosconi, ed. ICAR, Rome, Italy.
Haile-Mariam, M., and M. E. Goddard. 2010. Preliminary genetic analyses of voluntarily supplied disease data in Australian dairy herds. Anim. Prod. Sci. 50:186-192.

Heringstad, B. 2010. Genetic analysis of fertility-related diseases and disorders in Norwegian Red cows. J. Dairy Sci. 93:2751-2756.

Heringstad, B., Y. M. Chang, D. Gianola, and G. Klemetsdal. 2005a. Genetic association between susceptibility to clinical mastitis and protein yield in Norwegian dairy cattle. J. Dairy Sci. 88:15091514.

Heringstad, B., Y. M. Chang, D. Gianola, and G. Klemetsdal. 2005b. Genetic analysis of clinical mastitis, milk fever, ketosis, and retained placenta in three lactations of Norwegian Red cows. J. Dairy Sci. 88:3273-3281.

Heringstad, B., G. Klemetsdal, and J. Ruane. 2000. Selection for mastitis resistance in dairy cattle: A review with focus on the situation in the Nordic countries. Livest. Prod. Sci. 64:95-106.

Heringstad, B., G. Klemetsdal, and T. Steine. 2007. Selection responses for disease resistance in two selection experiments with Norwegian Red cows. J. Dairy Sci. 90:2419-2426.

Holtsmark, M., B. Heringstad, P. Madsen, and J. Ødegård. 2008. Genetic relationship between culling, milk production, fertility, and health traits in Norwegian Red cows. J. Dairy Sci. 91:4006-4012.

Kadarmideen, H. N., R. Thompson, and G. Simm. 2000. Linear and threshold model genetic parameters for disease, fertility and milk production in dairy cattle. Anim. Sci. 71:411-419.

Kelton, D. F., K. D. Lissemore, and R. E. Martin. 1998. Recommendations for recording and calculating the incidence of selected clinical diseases of dairy cattle. J. Dairy Sci. 81:2502-2509.

Koeck, A., F. Miglior, D. F. Kelton, and F. S. Schenkel. 2012. Alternative somatic cell count traits to improve mastitis resistance in Canadian Holsteins. J. Dairy Sci. 95:432-439.

Madsen, P., and J. Jensen. 2008. An User's Guide to DMU. A package for analyzing multivariate mixed models. Version 6 , release 4.7. Danish Institute of Agricultural Sciences, Tjele, Denmark.

Mee, J. F. 2008. Prevalence and risk factors for dystocia in dairy cattle: A review. Vet. J. 176:93-101.

Negussie, E., I. Strandén, and E. A. Mäntysaari. 2008. Genetic analysis of liability to clinical mastitis, with somatic cell score and production traits using bivariate threshold-linear and linear-linear models. Livest. Sci. 117:52-59.

Neuenschwander, T. F.-O. 2010. Studies on disease resistance based on producer-recorded data in Canadian Holsteins. PhD Thesis. University of Guelph, Guelph, Ontario, Canada.

Neuenschwander, T. F.-O., F. Miglior, J. Jamrozik, O. Berke, D. F. Kelton, and L. Schaeffer. 2012. Genetic parameters for producerrecorded health data in Canadian Holstein cattle. Animal 6:571578.

Onyiro, O. M., L. J. Andrews, and S. Brotherstone. 2008. Genetic parameters for digital dermatitis and correlations with locomotion, production, fertility traits, and longevity in Holstein-Friesian dairy cows. J. Dairy Sci. 91:4037-4046.

Østerås, O., H. Solbu, A. O. Refsdal, T. Roalkvam, O. Filseth, and A. Minsaas. 2007. Results and evaluation of thirty years of health recordings in the Norwegian dairy cattle population. J. Dairy Sci. 90:4483-4497.

Philipsson, J., and B. Lindhé. 2003. Experiences of including reproduction and health traits in Scandinavian dairy cattle breeding programmes. Livest. Prod. Sci. 83:99-112.

Pritchard, T., M. Coffey, R. Mrode, K. Moore, and E. Wall. 2010. Genetic parameters of udder health traits in Holstein Friesian UK dairy cattle. Paper 487 in Proc. 9th World Congr. Genet. Appl. Livest. Prod., Leipzig, Germany. Gesellschaft für Tierzuchtwissenschaften e.V (Ed.), Gießen, Germany.

Pryce, J. E., R. F. Veerkamp, R. Thompson, W. G. Hill, and G. Simm. 1997. Genetic aspects of common health disorders and measures of fertility in Holstein Friesian dairy cattle. Anim. Sci. 65:353-360.

Schnitzenlehner, S., A. Essl, and J. Sölkner. 1998. Retained placenta: Estimation of nongenetic effects, heritability and correlations to important traits in cattle. J. Anim. Breed. Genet. 115:467-478. 
Sordillo, L. M., G. A. Contreras, and S. L. Aitken. 2009. Metabolic factors affecting the inflammatory response in periparturient dairy cows. Anim. Health Res. Rev. 10:53-63.

Sørensen, M. K., J. Jensen, and L. G. Christensen. 2000. Udder conformation and mastitis resistance in Danish first-lactation cows: Heritabilities, genetic and environmental correlations. Acta Agric. Scand. A Anim. Sci. 50:72-82.

Thompson-Crispi, K. A., A. Sewalem, F. Miglior, and B. A. Mallard. 2012. Genetic parameters of adaptive immune response traits in Canadian Holsteins. J. Dairy Sci. 95:401-409.

van der Linde, C.. G. de Jong, E. P. C. Koenen, and H. Eding. 2010. Claw health index for Dutch dairy cattle based on claw trimming and conformation data. J. Dairy Sci. 93:4883-4891.
Zwald, N. R., K. A. Weigel, Y. M. Chang, R. D. Welper, and J. S Clay. 2004a. Genetic selection for health traits using producerrecorded data. I. Incidence rates, heritability estimates, and sire breeding values. J. Dairy Sci. 87:4287-4294.

Zwald, N. R., K. A. Weigel, Y. M. Chang, R. D. Welper, and J. S. Clay. 2004b. Genetic selection for health traits using producerrecorded data. II. Genetic correlations, disease probabilities, and relationships with existing traits. J. Dairy Sci. 87:4295-4302. 